\title{
Runderen versus paardachtigen in de vroeg-West-Europese geschiedenis
}

\author{
L. Devriese
}

Museumcollectie Diergeneeskundig Verleden, Merelbeke, Faculteit Diergeneeskunde, UGent, Salisburylaan 133, B-9820 Merelbeke, Belgium

\section{AMENVATTING}

Traditioneel wordt in onze geschiedenis een grote rol toebedeeld aan het paard als oorlogsinstrument en daarmee ook als middel om streken te veroveren en te koloniseren. Domesticatie van deze diersoort zou ervoor gezorgd hebben dat stammen die de paardrijkunst beheersten, dominant werden in onze streken. Minstens zo belangrijk echter, indien al niet meer, is de domesticatie van het rund. Die zorgde voor een extra voedselbron doordat, voor de mens onverteerbare planten, in hoofdzaak grassen, door runderen omgezet worden in voedzaam vlees en melk. Hun melkproductie, hoe gering ook, gaf een selectief voordeel aan mensen die de genetisch gedetermineerde eigenschap lactosetolerantie bezaten. Dit vinden we nu nog weerspiegeld in de prevalentie ervan in de huidige bevolking. In het tweede deel wordt de belangrijke rol van paarden in Noordwest-Europa als trekkracht geïllustreerd.

\section{INLEIDING}

Het gedomesticeerde rund kreeg in de geschiedschrijving over de prehistorie veel minder aandacht dan de paardachtigen. Onterecht. Dit werd recent duidelijk gemaakt door DNA-onderzoek in archeologische resten en naar de verspreiding van lactosetolerantie onder de bevolking. Dit is slechts een deel van het verhaal van de rol van grote huisdieren zoals we het zien in de door geschriften bevestigde geschiedenis. Trekkracht van grote huisdieren was ook heel belangrijk. In West-Europa werden al in de vroege middeleeuwen (ca 400 tot 1000 n.C.) paarden en kruisingen met ezels (overwegend muilezels) gebruikt in de akkerbouw.

\section{KOEIEN, LACTOSETOLERANTIE EN MIGRATIE}

De steppemigratie, die leidde tot de grootste genetische omslag die Europa ooit heeft gekend, wordt in de traditionele geschiedschrijving meestal voorgesteld als het resultaat van wilde veroveringstochten door woeste maar dappere benden (onze voorouders!) uitgevoerd. Die hadden in de steppen van centraal Azië en Zuidoost-Europa paarden getemd en leren gebruiken als een machtig instrument in het krijgsbedrijf. Dat is de courante versie van wat verkondigd wordt in de wijdverspreide "histoire bataille", de geschiedschrijving die men in de vorige eeuw het liefst beoefende.

Maar dat was niet zo, zo blijkt uit talrijke archeologisch-genetische studies samengevat door Krause en Trappe (2019). De nieuwe kolonisten leefden net als hun voorgangers in dorpen en bewerkten de omliggende akkers. Ze konden wel brons bewerken. Hiermee verlieten de mensen het steentijdperk, het lithicum. In het begin werd zowel steen als brons gebruikt om werktuigen en wapens te vervaardigen. Archeologen noemen die overgangsperiode het chalcolithicum, een tijdperk dat in sommige streken teruggaat tot zo'n zesduizend jaar geleden.

Belangrijker in de context van dit artikel is het feit dat de immigranten uit het oosten op minstens één cruciaal punt duidelijk verschilden van hun voorgangers en gedeeltelijk ook tijdgenoten, boeren in WestEuropa: ze waren gedreven koeienhouders. Terwijl de oorspronkelijke boeren nauwelijks meer dan twee koeien hielden, bezaten de nieuwkomers grote kudden. Met zijn vruchtbare bodem bood Europa nieuwe mogelijkheden. De voormalige nomaden hoefden niet langer verder te trekken met hun vee als een terrein afgegraasd was, ze konden zich ergens vestigen en massaal dieren houden op een vaste plek. De landbouw van Europa veranderde ingrijpend en daarmee ook de voeding. Dat vinden de moleculaire archeologen weerspiegeld in de lijkresten (vooral beenderen en tanden) die ze bestuderen.

Van de zowat twee liter die een koe 5000 jaar gele- 


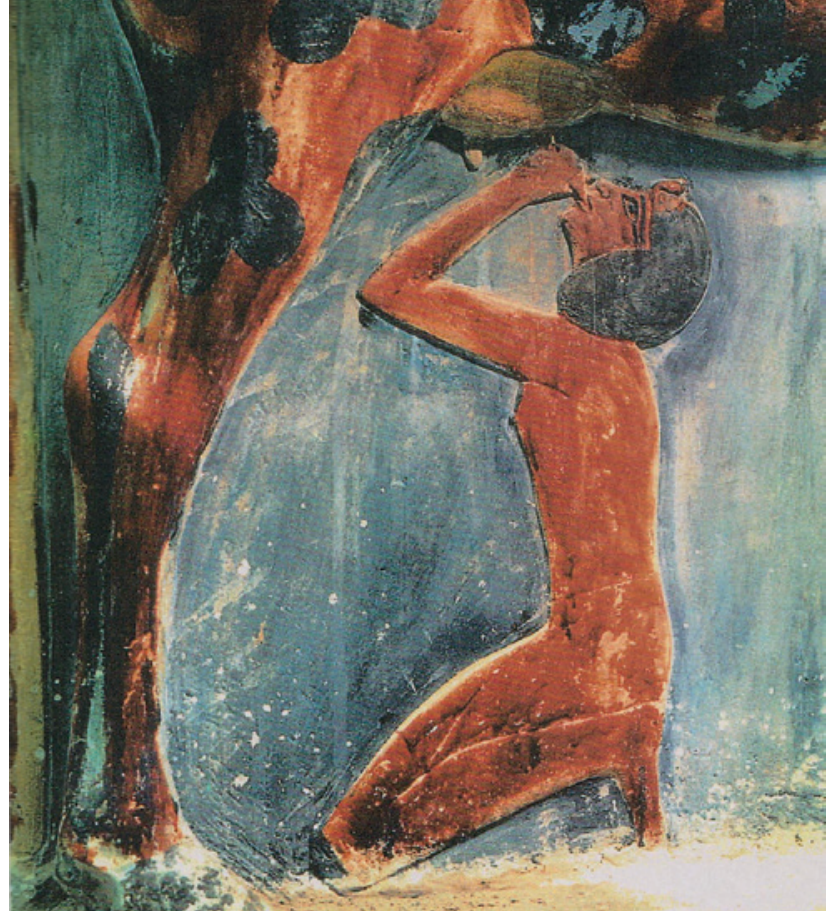

Figuur 1. Amenhotep II als kind. De toekomstige farao laaft zich aan de tepels van de koegodin Hathor om in haar goddelijke krachten te delen. Geverfde steen in de tempel van Tuthmoses III (1479-1425 v.C.) (uit: Fokkinga en Felius, 2010).

den gaf per dag, kon de eigenaar overigens maar een klein deel door zichzelf en zijn familie laten gebruiken (Figuur 1). De rest was voor de kalveren (Figuur 2). Als het overschot over de familie werd verdeeld, was dat nauwelijks genoeg voor een kleine portie per persoon. En dat was maar best ook, want voor het verteren van grotere hoeveelheden koeienmelk was het spijsverteringsstelsel van de Europeanen van toen niet geschikt. Veel mensen zijn het tegenwoordig nog steeds niet en hebben een lactose-intolerantie. In tegenstelling tot wat vaak gedacht wordt, gaat het daarbij niet om allergie of zelfs een ziekte, maar simpelweg om de genetische oertoestand van alle volwassen zoogdieren: alleen kinderen hebben de juiste enzymsamenstelling om melk te verdragen. Hun dunne darm neemt de melksuiker (lactose) op, die vervolgens met behulp van het enzym lactase wordt gesplitst in glucose en galactose, die gemakkelijk kunnen worden opgenomen in de bloedbaan.

Op volwassen leeftijd valt de productie van dit

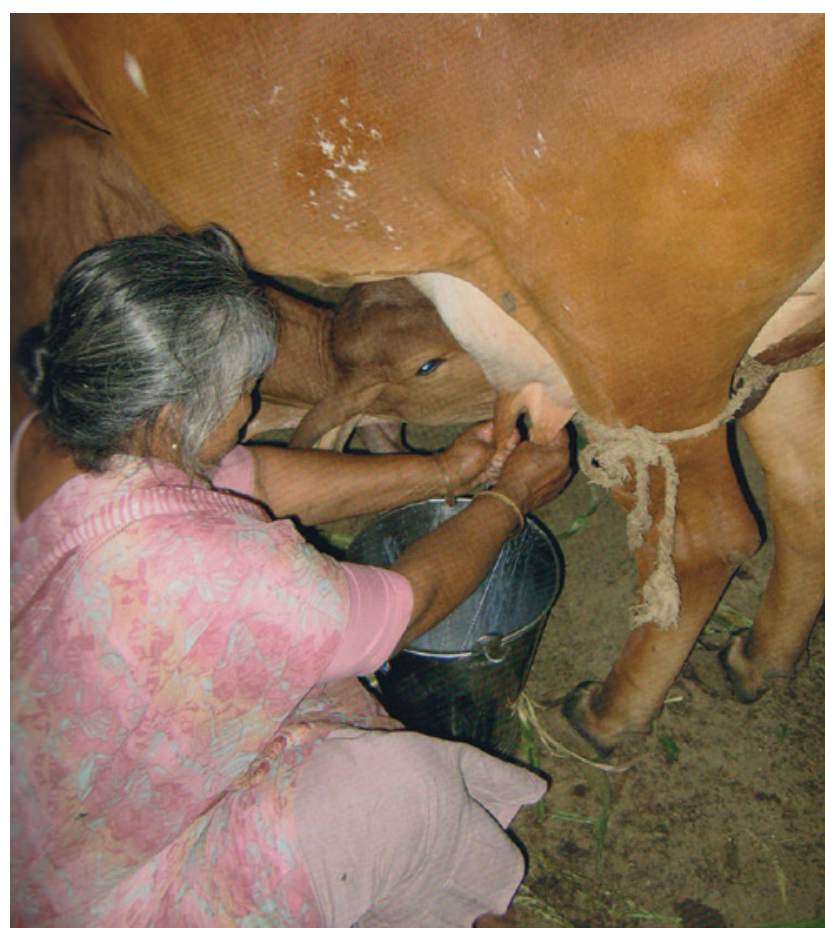

Figuur 2. Een Indiase vrouw melkt haar koe, maar laat een speen voor het kalf (uit: Fokkinga en Felius, 2010).

enzym stil. Melk verliest dan zijn voedingswaarde, omdat de suiker niet meer in energie kan worden omgezet. In plaats daarvan splitsen bacteriën in de endeldarm de melksuiker. Hierbij worden gassen geproduceerd met diarree en winderigheid tot gevolg. Gevaarlijk is dat niet, maar wel erg onaangenaam en soms ook pijnlijk. Evolutionair gezien is die programmering nuttig omdat baby's anders met familieleden, bijvoorbeeld hun vader, om moedermelk zouden moeten concurreren. Dit gebeurde maar al te dikwijls wanneer er voedseltekort was en naar alternatieve voedselbronnen gezocht moest worden. $\mathrm{Nu}$ is er natuurlijk geen reden meer voor een dergelijk biologisch beveiligingsmechanisme.

Tegenwoordig zijn er lactosevrije melkproducten en lactasepillen op de markt. De meeste volwassenen in Noord- en Midden-Europa hebben die niet nodig, en dat is te danken aan mutaties in de regulerende delen van het lactasegen. Deze mutaties zijn dominant (één kopij is voldoende) en zorgen voor zogenaamde lactasepersistentie. Mensen met die genetische aanpassing maken ook na de kinderleeftijd lactase aan.

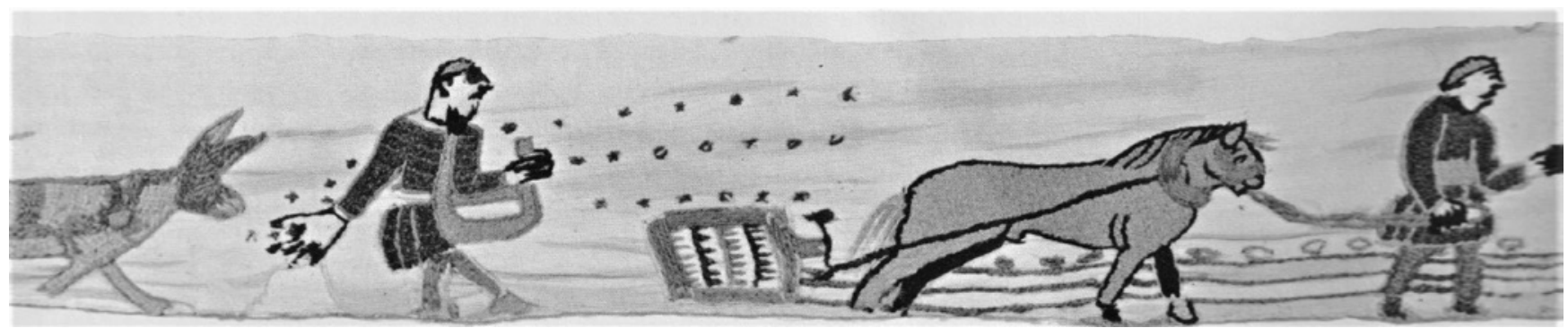

Figuur 3. Detail uit de "tapisserie de Bayeux" (Bayeux, Normandië, elfde eeuw). 


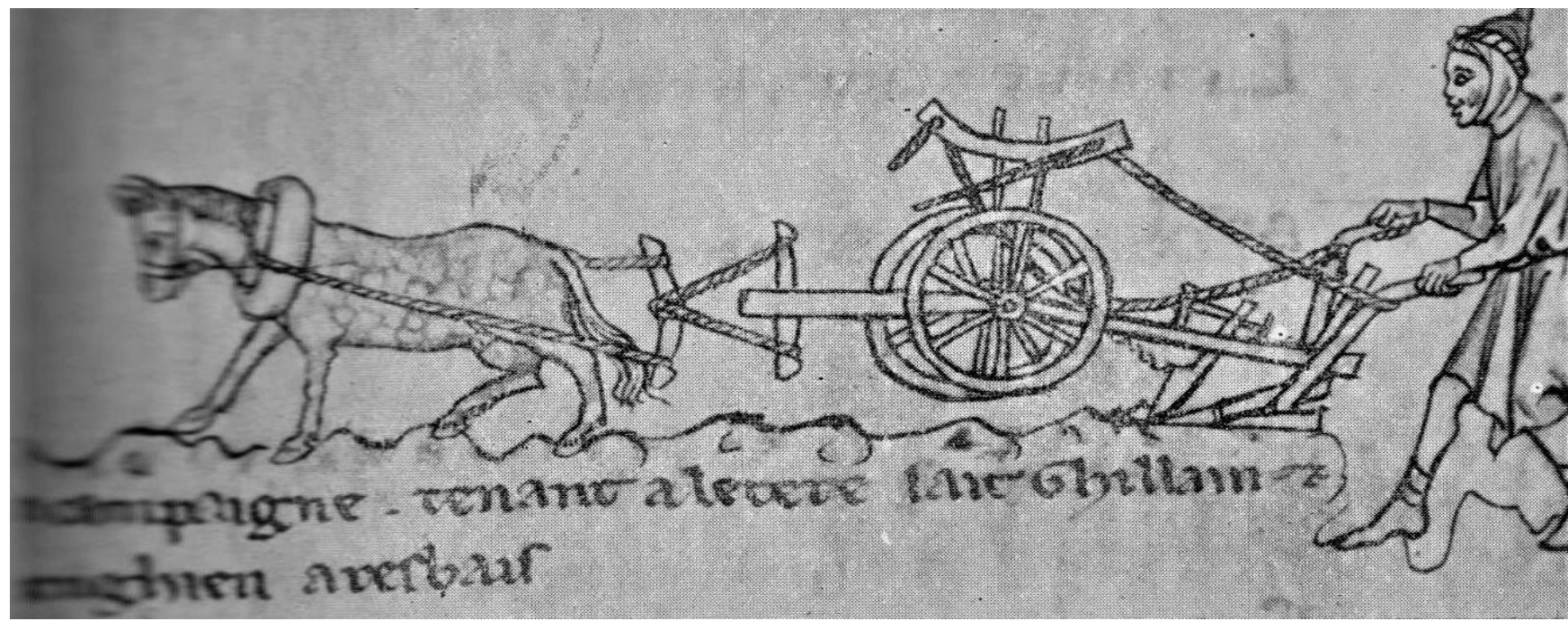

Figuur 4. Detail uit de "vieil rentier" van de heer van Oudenaarde (Koninklijke Bibliotheek, Brussel, dertiende eeuw).

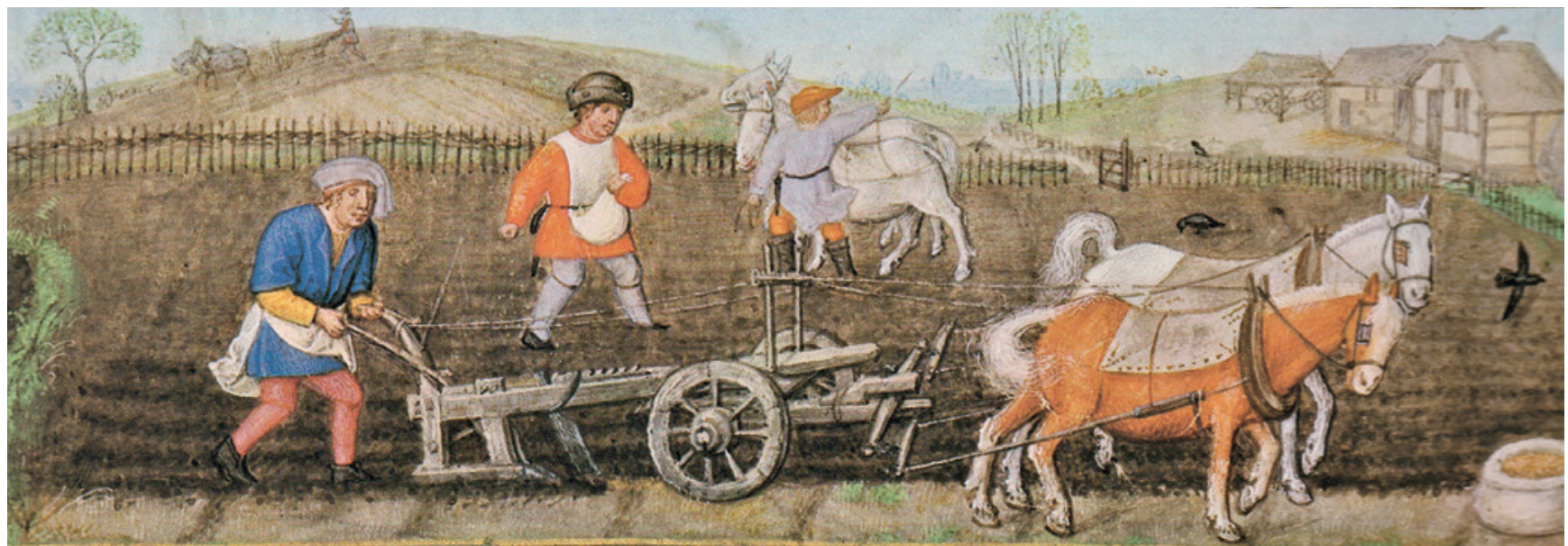

Figuur 5. Detail van een miniatuur uit het breviarium Mayer van den Bergh (in het gelijknamige museum, Antwerpen, einde vijftiende eeuw).

In sommige Europese landen is de lactasepersistentie nagenoeg $100 \%$ terwijl die meer naar het zuiden toe, bijvoorbeeld Griekenland slechts rond de $20 \%$ ligt. Lactosetolerantie leverde pas echt een evolutionair voordeel op, toen er meer melk beschikbaar kwam. Met de toenemende productie van melk verspreidde de mutatie zich verder in Europa en dat lijkt in Centraal-Europa met de immigratie van de koeienhoeders uit de steppe het geval te zijn geweest.

\section{VROEG GEBRUIK VAN TREKPAARDEN IN NOORDWEST-EUROPA}

Naast hun waarde als voedselbron hadden runderen nog een tweede heel belangrijk potentieel voordeel voor mensen: koeien en gecastreerde stieren (ossen) konden ingezet worden als trekkracht om goederen te vervoeren op sleden en karren, en vooral ook om akkers om te ploegen. In deze branche waren ze echter de enigen niet, ook gedomesticeerde paarden, ezels en kruisingen tussen deze twee soorten, vooral muildieren, product van paardenmerries met ezelhengsten, leverden trekkracht, minstens even goed, zo niet beter.

De oudste overgeleverde teksten over landbouwgeschiedenis tot en met de eerste eeuwen van onze tijdrekening, zijn vrijwel alle uit het Nabije Oosten en het Middellandse zeegebied afkomstig. Daaruit blijkt dat men vooral gebruik maakte van runderen en ezelachtigen om het land te bewerken met de primitieve gereedschappen van toen. De best gedocumenteerde antieke Latijnse tekst over landbouw De Re Rustica van de in Spanje geboren auteur Columella (eerste eeuw van onze jaartelling) besteedde verhoudingsgewijs slechts weinig aandacht aan paarden en hun kruisingen, des te meer aan runderen.

In zijn magistrale Geschiedenis van de Landbouw in België toonde Paul Lindemans (1952) aan dat paarden in onze streken niet enkel gekweekt werden voor gebruik door ridders (ruiters, "chevaliers") in de oorlogsvoering, maar dat ze al heel vroeg ingezet werden in de landbouw, vooral voor het bewerken van akkers 
met de primitieve ploegen en eggen van toen. Getuige dit citaat: 'In onze provincies werden de vazallen niet elk jaar opgeroepen ter heervaart. Er konden ettelijke jaren verlopen vooraleer dit eens gebeurde. Wat niet het geval was in de naburige grotere koninkrijken. Zo verliepen er soms vele jaren dat de ridder - boer of de dienstplichtige gebruiker van het heerlijk goed ongestoord op zijn landgoed kon boeren. Wat kon hij intussen doen met het sterke strijdros dat hij op stal moest houden? Het gezond boerenverstand spande het voor de ploeg en de wagen. Dat is stellig één van de omstandigheden die de oorzaak waren dat ons land tot de zeldzame landstreken behoorde en bleef behoren, waar het veldwerk sinds onheuglijke tijden met paarden bedreven werd. Overal elders gebruikte de boer een os. In veel landen is het gebruik van het paard als trekdier niet ouder dan de $19^{\text {de }}$ eeuw.'

Bijzonder waardevolle iconografische bronnen bevestigen dat beeld. Het beroemde "tapijt' ("tapisserie", eigenlijk borduurwerk, kort na 1066) van Bayeux dat de verovering van Engeland verhaalt door Willem de Bastaard, later Willem de Veroveraar genoemd, toont in een randversiering een stevig trekkend paard en een muildier (Figuur 3). Het is niet bekend waar dit precies geweven werd. Scandinavië of Engeland, neemt men tegenwoordig aan. Een tweede beeldende bron is de "vieil rentier" van de heer van Oudenaarde. Dit boek met jaarlijkse rente (cijnsverplichtingen verbonden aan onroerende eigendommen), pronkstuk van de koninklijke bibliotheek Albertina (Brussel) is nog meer illustratief, speciaal voor het akkerwerk met paarden, maar dateert van twee eeuwen later (Figuur 4). Een nauwkeurig weergegeven ploeg getrokken door een tweespan, zien we op een miniatuur (Figuur 5) in het kostbare breviarium Mayer van den Bergh (Antwerpen), aan het einde van de vijftiende eeuw gemaakt in de stijl van de Gents-Brugse school. Het oorspronkelijk trekken van voren (uiteenrijten van de aarde door het ploegmes), was toen al geëvolueerd tot omploegen, met de nadruk op 'om': het met onkruid begroeide akkeroppervlak wordt omgekeerd, zodat de bodem beter geschikt is om te bezaaien of te beplanten.

Een veel oudere (eind $9^{\text {de }}$ eeuw) bevestiging van het gebruik van paarden voor het akkerwerk in het noordwesten van Europa is te vinden in de verklaring van de Viking Ottar in een gesprek met de Zuid-Engelse koning Alfred. Hij bezat vooral rendieren, maar voor het klein beetje ploegwerk dat hij te doen had, gebruikte de Viking paarden (Skre, 2011).

\section{REFERENTIES}

Fokkinga, A, Felius, M. (2010). Koeien. Een Wonderbaarlijke Reis door de Wereld van het Rund. Toth, Bussum.

Krause, J., Trappe, T. (2019). Die Reise unserer Gene. Eine Geschichte über Uns und unserer Vorfahren. Ulstein, Berlin. In Nederlandse vertaling uitgegeven door Nieuw Amsterdam (2020). De Reis van onze Genen. Een Verhaal over ons en onze Voorouders.

Lindemans, P. (1952). Geschiedenis van de Landbouw in België. De Sikkel, Antwerpen. Deel 2, 290-390.

Pye, M., (2014). Aan de Rand van de Wereld. Originele titel: The Edge of the World, p. 89, noot 195.

Skre, D., (2011). Things from the Town: Artefacts and Inhabitants in Viking-Age Kaupang, Aarhus University Press. Geciteerd door Pye, 2014.

\footnotetext{
cc) Creative 2021 by the authors. Licensee Vlaams DierBelgium. This article is an open access article distributed under the terms and conditions of the Creative Commons Attribution (CC BY) license (http://creativecommons.org/licenses/by/4.0/).
} 